\title{
SARS-CoV-2 infection and recurrence of anti-glomerular basement disease: a case report
}

\author{
Alexander Winkler ${ }^{1}$, Emanuel Zitt', Hannelore Sprenger-Mähr ${ }^{1}$, Afschin Soleiman², Manfred Cejna ${ }^{3}$ and \\ Karl Lhotta ${ }^{1 *}$ (iD
}

\begin{abstract}
Background: Anti-glomerular basement membrane disease (GBM) disease is a rare autoimmune disease causing rapidly progressive glomerulonephritis and pulmonary haemorrhage. Recently, an association between COVID-19 and anti-glomerular basement membrane (anti-GBM) disease has been proposed. We report on a patient with recurrence of anti-GBM disease after SARS-CoV-2 infection.

Case presentation: The 31-year-old woman had a past medical history of anti-GBM disease, first diagnosed 11 years ago, and a first relapse 5 years ago. She was admitted with severe dyspnoea, haemoptysis, pulmonary infiltrates and acute on chronic kidney injury. A SARS-CoV-2 PCR was positive with a high cycle threshold. Anti-GBM autoantibodies were undetectable. A kidney biopsy revealed necrotising crescentic glomerulonephritis with linear deposits of $\operatorname{lgG}$, IgM and C3 along the glomerular basement membrane, confirming a recurrence of anti-GBM disease. She was treated with steroids, plasma exchange and two doses of rituximab. Pulmonary disease resolved, but the patient remained dialysis-dependent. We propose that pulmonary involvement of COVID-19 caused exposure of alveolar basement membranes leading to the production of high avidity autoantibodies by long-lived plasma cells, resulting in severe pulmonary renal syndrome.
\end{abstract}

Conclusion: Our case supports the assumption of a possible association between COVID-19 and anti-GBM disease.

Keywords: Anti-GBM disease, SARS-CoV-2, COVID-19, Glomerulonephritis, Case report

\section{Background}

Anti-glomerular basement disease (anti-GBM disease) is a rare small-vessel vasculitis. Characterized by the presence of circulating antibodies directed against the noncollagen $\mathrm{NC} 1$ domain of the alpha3 chain of collagen type IV in glomerular and alveolar basement membranes, the disease manifests as rapidly progressive crescentic glomerulonephritis and, in 40 to $60 \%$ of cases, with pulmonary haemorrhage [1].

\footnotetext{
* Correspondence: Karl.Ihotta@|khf.at

'Department of Internal Medicine 3 (Nephrology and Dialysis), Feldkirch Academic Teaching Hospital, Carinagasse 47, A-6800 Feldkirch, Austria Full list of author information is available at the end of the article
}

Recently, a report from London described a five-fold increased incidence of anti-GBM disease during the coronavirus pandemic. Four of the eight reported cases tested positive for SARS-Cov-2 IgM antibodies [2]. We here report the case of a young woman who experienced a recurrence of anti-GBM disease following an infection with the new coronavirus.

\section{Case presentation}

The now 31-year-old Caucasian woman, a heavy smoker (17 pack-years), had her first attack of anti-GBM disease in 2009 with life-threatening pulmonary haemorrhage and rapidly progressive glomerulonephritis. Plasma anti-

(c) The Author(s). 2021 Open Access This article is licensed under a Creative Commons Attribution 4.0 International License, which permits use, sharing, adaptation, distribution and reproduction in any medium or format, as long as you give appropriate credit to the original author(s) and the source, provide a link to the Creative Commons licence, and indicate if changes were made. The images or other third party material in this article are included in the article's Creative Commons licence, unless indicated otherwise in a credit line to the material. If material is not included in the article's Creative Commons licence and your intended use is not permitted by statutory regulation or exceeds the permitted use, you will need to obtain permission directly from the copyright holder. To view a copy of this licence, visit http://creativecommons.org/licenses/by/4.0/. The Creative Commons Public Domain Dedication waiver (http://creativecommons.org/publicdomain/zero/1.0/) applies to the data made available in this article, unless otherwise stated in a credit line to the data. 
GBM antibodies were detected (titre $137 \mathrm{U} / \mathrm{ml}$ ), and a renal biopsy showed linear IgG deposits along the glomerular basement membrane. She was treated with $1 \mathrm{~g}$ iv prednisolone for 3 days followed by $80 \mathrm{mg}$ orally, plasma exchange, and six cycles of iv cyclophosphamide $750 \mathrm{mg}$. After an allergic reaction to fresh frozen plasma, therapy was switched from plasma exchange to immunoadsorption using Ig-Therasorb ${ }^{\circ}$ columns with Sepharose-coupled polyclonal sheep antibodies against human immunoglobulins. She responded clinically well to treatment and anti-GBM antibodies became negative. Her serum creatinine in remission was $168 \mu \mathrm{mol} / \mathrm{L}$. Eight months later she acquired an influenza H1N1 virus infection with pneumonia and adult respiratory distress syndrome requiring mechanical ventilation. In 2012, parvovirus B19-associated perimyocarditis resulting in dilated cardiomyopathy was diagnosed. She was treated with intravenous immunoglobulin. A second episode of parvovirus B19-positive perimyocarditis occurred in 2015. Two months after the infection, the patient was re-admitted with haemoptysis, deteriorating renal function and a nephritic urinary sediment. A test for anti-GBM antibodies was borderline (titre $20 \mathrm{U} / \mathrm{mL}$ ). She was treated with $500 \mathrm{mg}$ iv prednisolone for 3 days followed by $80 \mathrm{mg}$ orally, plasma exchange and two 1-g doses of rituximab. Serum creatinine stabilized in the range of $180 \mu \mathrm{mol} / \mathrm{L}$.

In September 2020, the patient presented critically ill with severe dyspnoea, haemoptysis and anaemia. Heart rate was $120 / \mathrm{min}$, blood pressure $170 / 100$ $\mathrm{mmHg}$ and oxygen saturation 93\% when breathing ambient air. Within 1 week haemoglobin had fallen from 9.6 to $7.1 \mathrm{~g} / \mathrm{dL}$. Serum creatinine increased from around $270 \mu \mathrm{mol} / \mathrm{L}$ to $420 \mu \mathrm{mol} / \mathrm{L}$. Urinalysis revealed $3+$ proteinuria, 4+ haematuria and a highly nephritic sediment. Table 1 shows the most relevant results of laboratory investigations at first presentation of the patient.

Table 1 Main laboratory results on admission

\begin{tabular}{lll}
\hline Parameter & Result & Reference Range \\
\hline Haemoglobin & $9.6 \mathrm{~g} / \mathrm{dL}$ & $12-16 \mathrm{~g} / \mathrm{dL}$ \\
Thrombocytes & $247 \mathrm{G} / \mathrm{L}$ & $150-450 \mathrm{G} / \mathrm{L}$ \\
Leukocytes & $11.0 \mathrm{G} / \mathrm{L}$ & $3.4-10.4 \mathrm{G} / \mathrm{L}$ \\
Lymphocytes & $1.3 \mathrm{G} / \mathrm{L}$ & $0.7-4.8 \mathrm{G} / \mathrm{L}$ \\
D-dimer & $0.95 \mathrm{mg} / \mathrm{dL}$ & $<0.50 \mathrm{mg} / \mathrm{dL}$ \\
C-reactive protein & $2.94 \mathrm{mg} / \mathrm{dL}$ & $<0.50 \mathrm{mg} / \mathrm{dL}$ \\
Procalcitonin & $0.25 \mathrm{ng} / \mathrm{mL}$ & $<0.50 \mathrm{ng} / \mathrm{mL}$ \\
Creatinine & $420 \mu \mathrm{mol} / \mathrm{L}$ & $44.5-71.2 \mu \mathrm{mol} / \mathrm{L}$ \\
Urinary protein-creatinine ratio & $3.2 \mathrm{~g} / \mathrm{g}$ & $<0.11 \mathrm{~g} / \mathrm{g}$ \\
\hline
\end{tabular}

Radiology studies of the patient are presented in Fig. 1 A SARS-CoV-2 RT-PCR was positive with a cycle threshold $(\mathrm{Ct})>30$. SARS-CoV-2 antibodies were undetectable by ELISA. A diagnosis of COVID-19 was made, and the patient was treated with conventional oxygen supplementation and dexamethasone $6 \mathrm{mg}$ daily. Because of the medical history, haemoptysis and renal disease a recurrence of anti-GBM disease was suspected. Tests for anti-GBM antibodies and anti-neutrophil cytoplasmic antibodies were negative. A renal biopsy was performed. Of seven glomeruli three were completely sclerosed and three revealed fibrocellular crescents with florid segmental fibroid necrosis (Fig. 2a). Focal tubular atrophy with low-grade lymphomononuclear infiltration and moderate interstitial fibrosis were found. Immunohistochemistry revealed linear deposits of IgG, IgM and $\mathrm{C} 3$ along the glomerular basement membrane (Fig. 2b). No staining on tubular basement membranes was observed.

The diagnosis of recurrent anti-GBM disease was made. The patient was switched from dexamethasone to $60 \mathrm{mg}$ prednisolone, which was reduced to $40 \mathrm{mg}$ after 2 weeks and tapered to $10 \mathrm{mg}$ over the next 2 months. Furthermore, she received one dose of $1 \mathrm{~g}$ iv cyclophosphamide and two 1-g doses of rituximab. Cotrimoxazole was given for pneumocystis jirovecii prophylaxis. A series of seven plasma exchanges of four litres each led to remission of haemoptysis, and her clinical condition improved. After a symptom-free interval of 1 week, haemoptysis re-occurred. Another series of seven plasma exchanges was performed followed by rapid remission of pulmonary symptoms. The patient, however, remained dialysis-dependent. A time line of diagnoses and treatment modalities is provided in Table 2.

\section{Discussion and conclusions}

Anti-GBM disease is very rare with reported incidence rates between $<1$ to 1.79 per million population per year $[1,3,4]$. Although it is an autoimmune disease, reports of temporal and spatial clustering suggest that environmental factors such as infections may play a role in disease induction [4]. COVID-19 may be one such infection, as suggested by a report of a cluster of cases in London during the current pandemic. The authors report a five-fold increased incidence and four of eight patients had antibodies to SARS-CoV-2 [2]. Our case supports the assumption of a pathogenic link between COVID-19 and anti-GBM disease. The report from London and ours suggest that SARS-CoV-2 infection preceding anti-GBM disease is clinically mild or asymptomatic. There are, however, some unique aspects to our case. Whereas none of the cases in the London series had pulmonary involvement, our patient suffered from severe pulmonary haemorrhage. In contrast to the four 


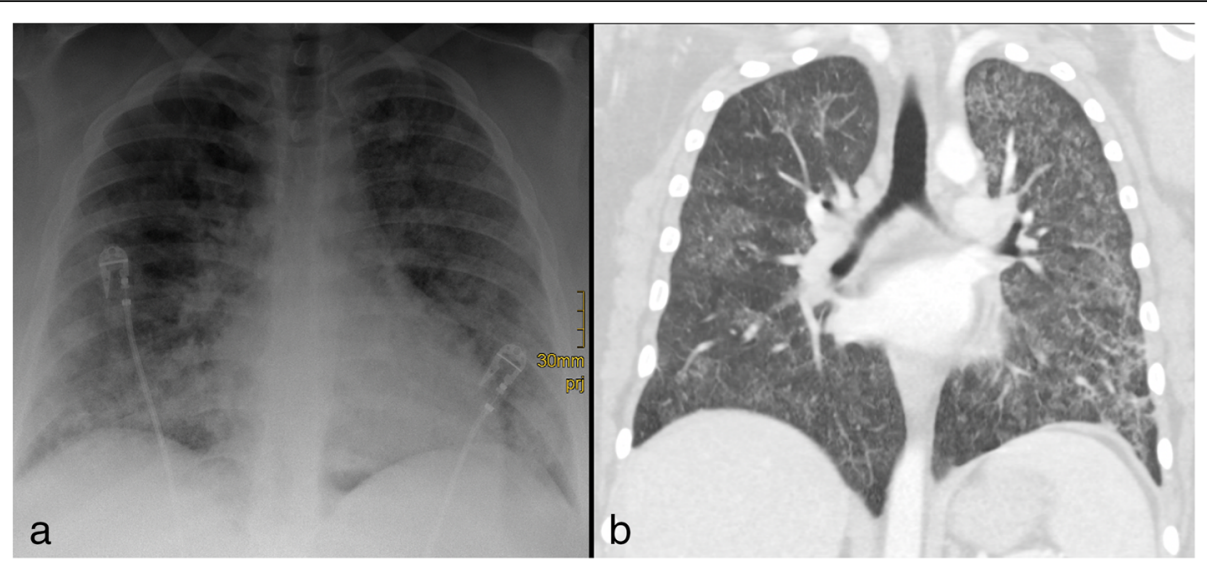

Fig. 1 a Chest x-ray at admission showed diffuse ground glass opacifications with minimal peripheral consolidations. b Four days later a CT scan of the chest revealed diffuse bilateral ground-glass opacities with minimal peripheral consolidations

reported London cases, our patient had a positive SARSCoV-2 PCR test, but no antibodies against the virus were detectable. This is not unusual, as antibodies are detected with highly sensitive assays in about $90 \%$ of patients [5]. Negative tests are preferentially found in asymptomatic cases such as ours [6]. In addition, antibodies may go undetected during the first 2 weeks of infection [7].

At initial presentation the symptoms of respiratory distress, radiologic findings, the positive SARS-Cov-2 PCR and negative anti-GBM autoantibody ELISA suggested a diagnosis of COVID-19, and the patient was treated accordingly. Haemoptysis, however, is not a classical manifestation of COVID-19, which made us suspicious that the patient could instead have a recurrence of anti-GBM disease. This was eventually confirmed by renal histology. We therefore propose that the clinical symptoms and radiology findings were already caused by anti-GBM disease, and not COVID-19.

As SARS-CoV-2 PCR tests are $100 \%$ specific, there is no doubt that our patient had contracted the infection. The patient did not report any prodromal symptoms compatible with COVID-19 in the last few weeks. The onset of disease with pulmonary haemorrhage was rather abrupt. The positive SARS-CoV-2 PCR with a high cycle threshold suggests that the patient had contracted the infection only very recently, probably 2 to 3 weeks previous [8]. This means that anti-GBM disease occurred rather rapidly after the SARS-CoV-2 infection, probably because our patient was not having her first attack, but rather her second recurrence of anti-GBM disease.

SARS-CoV-2 infects pulmonary endothelial cells [9]. Consecutive complement activation and inflammation cause endothelial injury, leading to exposure of the basement membrane [10]. This sequence of events may release the $\mathrm{NC1}$ antigen into the circulation. The autoantigen may then have stimulated long-lived memory plasma cells reacting to $\mathrm{NC} 1$ to produce and secrete autoantibodies, resulting in rapid anti-GBM disease recurrence in our patient. Proteinuria and haematuria have been described in a large proportion of patients with COVID-19, suggestive of renal, possibly glomerular damage during the infection [11]. Therefore, tissue damage in the alveoli in the lung and glomeruli in the kidney may make the autoantigens in the basement membrane accessible to circulating antibodies, eventually leading to pulmonary renal syndrome. Intercurrent infection could also lead to unspecific bystander activation of pre-existing autoreactive $\mathrm{T}$ and $\mathrm{B}$ lymphocytes

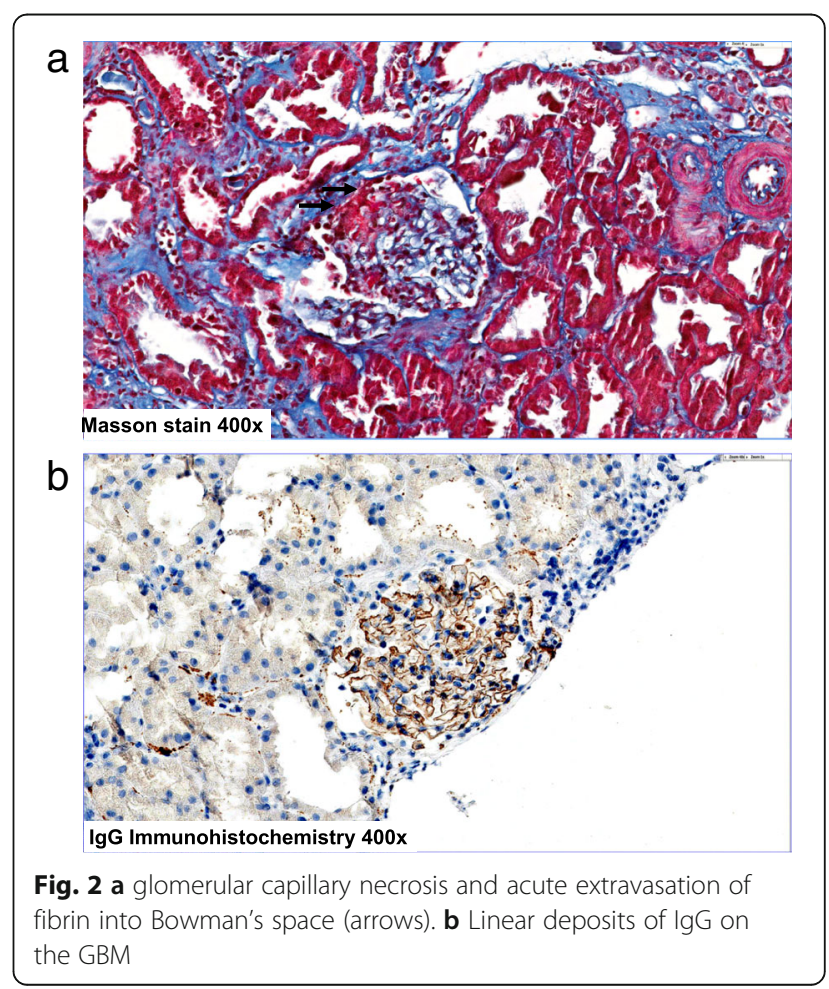


Table 2 Time line of diagnoses and treatments

\begin{tabular}{|c|c|c|c|c|c|c|c|c|}
\hline \multirow[t]{2}{*}{ Date } & \multirow{2}{*}{ Diagnosis } & \multirow{2}{*}{$\begin{array}{l}\text { 04/2009 } \\
\begin{array}{l}\text { Anti-GBM } \\
\text { disease }\end{array}\end{array}$} & \multirow{2}{*}{$\begin{array}{l}\text { 12/2009 } \\
\text { H1N1 } \\
\text { pneumonia }\end{array}$} & \multirow{2}{*}{$\begin{array}{l}\text { 09/2012 } \\
\text { Parvovirus B19 } \\
\text { Myocarditis }\end{array}$} & \multirow{2}{*}{$\begin{array}{l}\text { 03/2015 } \\
\text { Parvovirus B19 } \\
\text { Myocarditis }\end{array}$} & \multirow{2}{*}{$\begin{array}{l}\text { 05/2015 } \\
\text { Anti-GBM } \\
\text { disease }\end{array}$} & \multirow{2}{*}{$\begin{array}{l}08 / \\
2020 ? \\
\text { COVID- } \\
19\end{array}$} & \multirow{2}{*}{$\begin{array}{l}\text { 09/2020 } \\
\text { Anti-GBM } \\
\text { disease }\end{array}$} \\
\hline & & & & & & & & \\
\hline \multirow[t]{7}{*}{ Treatment } & $P E(n)$ & 2 & & & & 13 & & 14 \\
\hline & IAS (n) & 9 & & & & & & \\
\hline & IVS & $3 \times 1000 \mathrm{mg}$ & & & & $3 \times 500 \mathrm{mg}$ & & \\
\hline & os & 80 mg & & & & 80 mg & & 60 mg \\
\hline & IVCYC & $6 \times 750 \mathrm{mg}$ & & & & & & 1000 mg \\
\hline & $\mathbf{R}$ & & & & & $2 \times 1 \mathrm{~g}$ & & $2 \times 1 \mathrm{~g}$ \\
\hline & IVIG & & & $2 \times 10 \mathrm{~g}$ & $2 \times 10 \mathrm{~g}$ & & & \\
\hline
\end{tabular}

Abbreviations: PE Plasma exchange, IAS Immunoadsorption, IVS Intravenous steroids, OS Oral steroids, IVCYC Intravenous cyclophosphamide, $R$ Rituximab, IVIG Intravenous immunoglobulin

[12]. In addition, any concurrent infection may precipitate or aggravate pulmonary haemorrhage and glomerular damage in anti-GBM disease [13]. A clear causal mechanism, however, between SARS-CoV-2 infection and anti-GBM disease has thus far not been established.

Rituximab is an effective alternative to cyclophosphamide in the treatment of anti-GBM disease [14, 15]. Rituximab was also successful in the treatment of the patient's first relapse. She had already received cyclophosphamide for her initial attack. Therefore, we decided to change treatment from cyclophosphamide to rituximab in order not to increase the cumulative dose of this rather toxic medication in a young woman.

Another interesting aspect of our case is the continuous decrease of anti-GBM antibodies detected by antigen-specific ELISA during her initial disease and recurrences. At the first attack 11 years earlier, antibodies were detected at a high titre. During the first recurrence 5 years ago, autoantibodies were present, but only borderline. At the current flare-up, autoantibodies were undetectable. A kidney biopsy, however, clearly showed linear autoantibody binding to the glomerular basement membrane. We suggest that affinity maturation of the autoantibodies leads to their rapid and avid binding to the antigen and disappearance from blood, rendering them undetectable with conventional ELISA tests. Alternatively, chronic antigen stimulation may have caused a switch from IgG1 to IgG4 isotype anti-GBM antibodies, which are not detected by conventional ELISA [16, 17]. Further IgG subtype classification by immunochemistry in the renal biopsy would allow to identify these rare IgG4 antibodies but was not available.

Despite a negative autoantibody ELISA we decided to treat the patient with plasma exchange. Monitoring the efficacy and frequency of plasma exchange by antibody titres is not possible in that situation. The early relapse after seven plasma exchanges may be due to the strong and probably prolonged binding of the autoantibodies to the basement membranes.

In conclusion, we report a patient with anti-GBM disease, who had a recurrence of the disease after infection with the new coronavirus SARS-CoV-2, which confirms earlier reports that COVID-19 may be a trigger of this life-threatening autoimmune disease. More clinical and experimental investigations are necessary to further establish and confirm a causal link between these diseases. Initial differentiation between COVID-19 and anti-GBM disease may be challenging.

\section{Abbreviations}

SARS-CoV-2: Severe acute respiratory syndrome coronavirus 2; COVID19: Coronavirus disease 2019; GBM: Glomerular basement membrane; ELISA: Enzyme-linked immunoassay; RT-PCR: Reverse transcription polymerase chain reaction

\section{Acknowledgements}

None.

Authors' contributions

$\mathrm{AW}, \mathrm{EZ}, \mathrm{HS}$ and $\mathrm{KL}$ were involved in clinical management of the patient. AS did the histology and $\mathrm{MC}$ the radiology studies. All authors have read and approved the manuscript.

Authors' information

None.

Funding

None.

Availability of data and materials

Data sharing is not applicable.

Ethics approval and consent to participate

Not applicable.

Consent for publication

Written informed consent was obtained from the patient for publication of the case report including images.

Competing interests

The authors have no competing interests to declare. 


\section{Author details}

'Department of Internal Medicine 3 (Nephrology and Dialysis), Feldkirch Academic Teaching Hospital, Carinagasse 47, A-6800 Feldkirch, Austria. ${ }^{2}$ Pathology, Cytodiagnostics and Molecular Pathology, Hall in Tirol, Austria. ${ }^{3}$ Institute for Diagnostic and Interventional Radiology, Feldkirch Academic Teaching Hospital, Feldkirch, Austria.

Received: 26 November 2020 Accepted: 18 February 2021

\section{Published online: 27 February 2021}

\section{References}

1. McAdoo SP, Pusey CD. Anti-Glomerular Basement Membrane Disease. Clin J Am Soc Nephrol. 2017;12:1162-72. https://doi.org/10.2215/CJN.01380217.

2. Prendecki M, Clarke C, Cairns T, Cook T, Roufosse C, Thomas D, et al. Antiglomerular basement membrane disease during the COVID-19 pandemic. Kidney Int. 2020;98:780-1. https://doi.org/10.1016/j.kint.2020.06.009.

3. Taylor DM, Yehia M, Simpson IJ, Thein H, Chang Y, de Zoysa JR. Antiglomerular basement membrane disease in Auckland. Intern Med J. 2012;42: 672-6. https://doi.org/10.1111/j.1445-5994.2011.02621.x.

4. Canney M, O'Hara PV, McEvoy CM, Medani S, Connaughton DM, Abdalla AA, et al. Spatial and temporal clustering of anti-glomerular basement membrane disease. Clin J Am Soc Nephrol. 2016;11:1392-9. https://doi.org/1 0.2215/CJN.13591215.

5. Gudbjartsson DF, Norddahl GL, Melsted P, Gunnarsdottir K, Holm H, Eythorsson $\mathrm{E}$, et al. Humoral immune response to SARS-CoV-2 in Iceland. N Engl J Med. 2020;383:1724-34. https://doi.org/10.1056/NEJMoa2026116.

6. Pollán M, Pérez-Gómez B, Pastor-Barriuso R, Oteo J, Hernán MA, PérezOlmeda $\mathrm{M}$, et al. Prevalence of SARS-CoV-2 in Spain (ENE-COVID): a nationwide, population-based seroepidemiological study. Lancet. 2020;396: 535-44. https://doi.org/10.1016/S0140-6736(20)31483-5.

7. Deeks JJ, Dinnes J, Takwoingi Y, Davenport C, Spijker R, Taylor-Phillips S, et al. Antibody tests for identification of current and past infection with SARS-CoV-2. Cochrane Database Syst Rev. 2020;6:CD013652. https://doi. org/10.1002/14651858.CD013652.

8. Salvatore PP, Dawson P, Wadhwa A, Rabold EM, Buono S, Dietrich EA, et al. Epidemiological correlates of PCR cycle threshold values in the detection of SARS-CoV-2. Clin Infect Dis. 2020. https://doi.org/10.1093/cid/ciaa1469.

9. Ackermann M, Verleden SE, Kuehnel M, Haverich A, Welte T, Laenger F, et al. Pulmonary vascular Endothelialitis, thrombosis, and angiogenesis in Covid19. N Engl J Med. 2020;383:120-8. https://doi.org/10.1056/NEJMoa2015432.

10. Perico L, Benigni A, Casiraghi F, Ng LFP, Renia L, Remuzzi G. Immunity, endothelial injury and complement-induced coagulopathy in COVID-19. Nat Rev Nephrol. 2020. https://doi.org/10.1038/s41581-020-00357-4.

11. Pei G, Zhang Z, Peng J, Liu L, Zhang C, Yu C, et al. Renal involvement and early prognosis in patients with COVID-19 pneumonia. J Am Soc Nephrol. 2020;31:1157-65. https://doi.org/10.1681/ASN.2020030276.

12. McAdoo SP, Pusey CD. Clustering of anti-GBM disease: clues to an environmental trigger? Clin J Am Soc Nephrol. 2016;1 1:1324-6. https://doi. org/10.2215/CJN.05580516.

13. Kluth DC, Rees AJ. Anti-glomerular basement membrane disease. J Am Soc Nephrol. 1999;10:2446-53.

14. Uematsu-Uchida M, Ohira T, Tomita S, Satonaka H, Tojo A, Ishimitsu T. Rituximab in treatment of anti-GBM antibody glomerulonephritis: A case report and literature review. Medicine (Baltimore). 2019;98:e17801. https:// doi.org/10.1097/MD.0000000000017801.

15. Touzot M, Poisson J, Faguer S, Ribes D, Cohen P, Geffray L, et al. Rituximab in anti-GBM disease: a retrospective study of 8 patients. J Autoimmun. 2015 60:74-9. https://doi.org/10.1016/j.jaut.2015.04.003.

16. Thibaud V, Rioux-Leclerca N, Vigneau C, Morice S. Recurrence of Goodpasture syndrome without circulating anti-glomerular basement membrane antibodies after kidney transplant, a case report. BMC Nephrol. 2019;20:6. https://doi.org/10.1186/s12882-018-1197-6.

17. Ohlsson S, Herlitz H, Lundberg S, Selga D, Mölne J, Wieslander J, Segelmark M. Circulating anti-glomerular basement membrane antibodies with predominance of subclass lgG4 and false-negative immunoassay test results in anti-glomerular basement membrane disease. Am J Kidney Dis. 2014;63. 289-93. https://doi.org/10.1053/j.ajkd.2013.08.032.

\section{Publisher's Note}

Springer Nature remains neutral with regard to jurisdictional claims in published maps and institutional affiliations.

\section{Ready to submit your research? Choose BMC and benefit from:}

- fast, convenient online submission

- thorough peer review by experienced researchers in your field

- rapid publication on acceptance

- support for research data, including large and complex data types

- gold Open Access which fosters wider collaboration and increased citations

- maximum visibility for your research: over $100 \mathrm{M}$ website views per year

At BMC, research is always in progress.

Learn more biomedcentral.com/submissions 